Original Research Article

\title{
Effect of tamsulosin on blood glucose levels in euglycemic and alloxan induced diabetic rats and its interaction with glibenclamide
}

\author{
Sumit Satpute ${ }^{1}$, Rajan Nerurkar ${ }^{2}$, Manish Kokne ${ }^{3 *}$
}

\begin{abstract}
${ }^{1}$ Department of Pharmacology, Chandrapur Government

Medical College, Chandarpur, Maharashtra, India

${ }^{2}$ Department of Pharmacology, Topiwala National Medical College, Mumbai, Maharashtra, India

${ }^{3}$ Department of Pharmacology, HBTMC and Cooper Hospital, Mumbai, Maharashtra, India
\end{abstract}

Received: 28 May 2018

Accepted: 26 June 2018

*Correspondence to:

Dr. Manish Kokne,

Email: manishkkn1120@ gmail.com

Copyright: (C) the author(s), publisher and licensee Medip Academy. This is an openaccess article distributed under the terms of the Creative Commons Attribution NonCommercial License, which permits unrestricted noncommercial use, distribution, and reproduction in any medium, provided the original work is properly cited.

\begin{abstract}
Background: To evaluate the effect of tamsulosin on blood glucose levels in euglycaemic rats and to investigate the effect of glibenclamide, tamsulosin and their combination on alloxan induced diabetic rats.

Methods: Albino male wistar rats were randomly assigned into 6 groups (2 euglycaemic and 4 alloxan induced diabetic rats groups). In Euglycaemic rats either normal saline $(0.5 \mathrm{ml} \mathrm{P.O)} \mathrm{or} \mathrm{tamsulosin}(0.072 \mathrm{mg} / \mathrm{kg} \mathrm{P.O})$ were given and blood glucose levels was estimated at $0 \mathrm{hr}, 30 \mathrm{~min}, 1 \mathrm{hr}, 2 \mathrm{hr}, 4 \mathrm{hr}$ on day 1 and at $0 \mathrm{hr}$ and $1 \mathrm{hr}$ on day 3 and day 7 . Four groups of diabetic rats were given normal saline (0.5ml P.O), glibenclamide (5mg/kg P.O), tamsulosin (0.072mg/kg P.O), combination of glibenclamide and tamsulosin respectively and blood glucose levels were estimated on day 1, 3 and 7. Repeated measures ANOVA or paired ' $t$ 'test were used for within group comparison and one way ANOVA or unpaired ' $t$ ' test were used for between group comparison.

Results: In euglycaemic rats tamsulosin caused significant rise in blood glucose levels at $1 \mathrm{hr}$ on all days and in diabetic rats tamsulosin itself did not cause any significant alteration in blood glucose levels. However, its combination with glibenclamide delayed the onset of hypoglycemic effect of glibenclamide \& also reduced its hypoglycemic effect.

Conclusions: Tamsulosin significantly increase blood glucose level in euglycaemic rats and it interact with Glibenclamide to reduce its hypoglycemic activity in diabetic rats.
\end{abstract}

Keywords: Alloxan induced diabetic rats, Glibenclamide, Tamsulosin

\section{INTRODUCTION}

Diabetes mellitus (DM) is a heterogeneous group of disease, characterized by a state of chronic hyperglycemia, resulting from a diversity of etiologies, environmental and genetic, acting jointly. Diabetes has emerged as a major health problem in developing world. It is associated with many co-morbid conditions such as hypertension, obesity, cardiovascular disorder, dyslipidemia, mostly due to hyperglycemia caused by insulin deficiency or resistance to insulin. ${ }^{1}$ In elderly male patients suffering from diabetes mellitus (DM), benign prostatic hyperplasia (BPH) is often associated for which $\alpha$ receptor antagonist such as prazosin, doxazosin, and selective $\alpha_{1 \mathrm{~A}}$ antagonist such as tamsulosin are frequently used. ${ }^{2}$ Obesity, elevated blood glucose level and diabetes have been mentioned as risk factors for benign prostatic hyperplasia. ${ }^{2}$ Sulfonylureas are effective oral hypoglycemic agents that have been widely used in clinical practice. ${ }^{3}$ The hypoglycemic effect of all 
sulfonylureas predominantly occurs through inhibition of adenosine triphosphate-sensitive potassium channels in $\beta$ cells of the pancreas. ${ }^{4}$ Benign prostatic hyperplasia (BPH) is the most common benign tumor in men, and its incidence is age related. i.e age $>60$ years or older. Alpha 1 adrenergic receptor antagonists are the main treatment for patients with BPH presenting with obstructive urinary symptoms and are used by $80 \%$ of physicians as the first agent to treat this common condition in the aging men. ${ }^{5}$ Three subtypes of $\alpha$ receptors exist: $\alpha_{1 \mathrm{~A}}, \alpha_{1 \mathrm{~B}}$, and $\alpha_{1 \mathrm{D}}$. $\alpha_{1 \mathrm{~A}}$ composes $70 \%$ of the human prostatic receptors, but this percentage may actually increase to $80 \%$ in patients with BPH. Tamsulosin is the first selective $\alpha_{1 \mathrm{~A}}$ adrenoceptor antagonist. So it is mainly indicated for the treatment of urinary tract symptoms related to BPH. One study had reported that 3 patients developed hyperglycemia in association with the use of tamsulosin for the treatment of BPH. ${ }^{6}$ All these patients were suffering from diabetes mellitus and were receiving insulin therapy. Hyperglycemia recovered after the withdrawal of tamsulosin. A pharmacological mechanism for this adverse drug reaction is suggested: stimulation of the $\alpha_{1}$ receptor is one of the insulin-independent pathways for glucose uptake; hence inhibition might increase plasma glucose concentrations. ${ }^{6}$ Study shows that $\alpha_{1}$ blocker doxazosin shows beneficial effects on glucose control in diabetes mellitus. ${ }^{7,8}$ These studies suggest that $\alpha$ blockers may have variable effect on blood glucose levels in diabetic patients.

Concomitant addition of sulfonylureas and tamsulosin may influence hypoglycemic action of sulfonylureas. In view of these contradictory reports regarding effect of $\alpha$ blockers on the blood glucose levels therefore we decided to evaluate the effect of tamsulosin on euglycemic and alloxan induced diabetic rats and its interaction with glibenclamide.

\section{METHODS}

The study was conducted in department of pharmacology, TNMC and Nair hospital, Mumbai after taking permission from Institutional Animal Ethics Committee.

\section{Study animals}

36 Albino wistar rats of male sex weighing 150 to $250 \mathrm{gm}$ were used for the experiment. There were total six groups in the study. Six rats were included per group (Table 1). Temperature and humidity were maintained properly. The rats were allowed one week period of acclimatization in institutional animal house. Food and water were given ad libitum. Glucometer standardization was done.

Table 1: Types of groups.

\begin{tabular}{|lllll|}
\hline Group no. & Group description & Drugs & Dose and route & Duration (Days) \\
\hline 1 & Non diabetic & Normal saline & $0.5 \mathrm{ml}(\mathrm{P} . \mathrm{O})$ & 7 \\
\hline 2 & Non diabetic & Tamsulosin & $0.072 \mathrm{mg} / \mathrm{kg}(\mathrm{P} . \mathrm{O})$ & 7 \\
\hline 3 & Diabetic & Normal saline & $0.5 \mathrm{ml}(\mathrm{P.O})$ & 7 \\
\hline 4 & Diabetic & Glibenclamide & $5 \mathrm{mg} / \mathrm{kg}(\mathrm{P} . \mathrm{O})$. & 7 \\
\hline 5 & Diabetic & Tamsulosin & $0.072 \mathrm{mg} / \mathrm{kg}($ P.O) & 7 \\
\hline 6 & Diabetic & Glibenclamide $(5 \mathrm{mg} / \mathrm{kg})+$ & Both P.O. & 7 \\
\hline
\end{tabular}

\section{Study procedure}

The rats were fasted overnight for 12 hours before the start of the experiment and were continued fasting till the end of the experiment (i.e. till the last blood collection of the respective day). Coprophagy was prevented by keeping the rats on a grid placed at the bottom of the cage.

The solutions of Tamsulosin and Glibenclamide were made in normal saline for oral administration to rats. This solution was fed through an oral feeding tube to each rat. The dose of each rat was calculated depending upon the weight of the rat. Diabetes was induced by single dose (120 $\mathrm{mg} / \mathrm{kg}$ i.p.) of freshly prepared solution of $5 \%$ Alloxan monohydrate dissolved in normal saline. All the rats were given $10 \%$ Glucose solution orally for 24 hours after Alloxan injection to prevent hypoglycemia. The induction of diabetes was confirmed after $48 \mathrm{~h}$ by blood glucose estimation and rats with blood glucose level more than $250 \mathrm{mg} / \mathrm{dl}$ were selected for the study.

Study was done in 2 parts. In the $1^{\text {st }}$ part 2 groups of 6 normal rats were used and in $2^{\text {nd }}$ part, 24 alloxan induced diabetic rats were divided into 4 groups of 6 each and were given normal saline, glibenclamide, tamsulosin and their combination as shown in the Table 1 .

After this, the rats received an oral dose of Normal saline, Tamsulosin and Glibenclamide as given in Table 1.

The blood glucose levels were estimated at 0 hour (before the dose), 0.5 -hour, 1 hour, 2 hour, and 4 hour as day 1 and at 0 hour and 1 hour on day 3 and day 7 . 


\section{Method of blood glucose estimation}

The rats were fasted overnight from 8.00 p.m. for 12 hours before the start of the experiment and were kept fasting till the end of the experiment (i.e. till the last blood collection of the day). On the day of experiment, drugs were given at 8.00 am onwards. All the rats were weighed before the drug administration. Baseline blood glucose values $(0$ hour) before the drug administration were estimated in the rats as follows.

Blood sample was collected from rat tail vein by pin prick method. Each rat was taken out from the cage and placed in rat holder. Tail vein was identified, and Xylene was applied over it to dilate it. Required amount of blood was obtained on glucose strips. Blood glucose levels were estimated using the Optium Xceed Glucometer and glucose strips by Abbott.

\section{Statistical analysis}

The significance of the difference between the mean blood glucose levels at various time intervals within the group was estimated using Repeated Measures ANOVA and between different groups was estimated using One Way ANOVA, followed by Tukey / Dunnet post hoc test. In group 1 and group 2 "Paired t test" (two tailed) was used to compare mean blood glucose levels before and 1 hour after the administration of drugs on days 3 and 7 and Unpaired ' $t$ ' test was used to compare the change in blood glucose levels on day 3 and day 7 . $\mathrm{P}<0.05$ was considered significant. Graphpad Prism version 5.03 and Microsoft Excel 2007 were used. Data displayed as mean \pm SD.

\section{RESULTS}

In Euglycemic rats on within group comparison we found that mean blood glucose values were found to be statistically significantly increased in groups 1 and groups 2 at 1 hour time intervals as compared to baseline value at 0 hour in respective group on day 1 . On day 3 and 7 the mean blood glucose level at 1 hour was significantly high as compared to 0 hour $(\mathrm{p}=0.0059)$ in Group 2 (Table 2 and 3).

Table 2: Mean blood glucose levels (mg/d) in nondiabetic rats on day 1 at various time intervals.

\begin{tabular}{|lll|}
\hline Time & $\begin{array}{l}\text { Group 1 } \\
\text { (Normal Saline) }\end{array}$ & $\begin{array}{l}\text { Group 2 } \\
\text { (Tamsulosin) }\end{array}$ \\
\hline 0 & $62 \pm 6.36$ & $66.67 \pm 4.68$ \\
\hline $0.5 \mathrm{hr}$ & $68.00 \pm 7.40$ & $97.00 \pm 17.04$ \\
\hline $1 \mathrm{hr}$ & $78.17 \pm 11.72 * *$ & $107.83 \pm 15.51 * * *$ \\
\hline $2 \mathrm{hr}$ & $71.00 \pm 9.55$ & $84.33 \pm 9.03$ \\
\hline $4 \mathrm{hr}$ & $69.84 \pm 6.08$ & $83.33 \pm 6.89$ \\
\hline $\begin{array}{l}\mathrm{p} \text { value } \\
\text { RM } \\
\text { ANOVA }\end{array}$ & 0.013 & $<0.0001$ \\
\hline$* * * \mathrm{p}<0.001, * * \mathrm{p}<0.01)$ & \\
\hline
\end{tabular}

Asterisk indicates within group comparison with baseline value at 0 hour in respective group by using Dunnett's post hoc test.

Table 3: Mean blood glucose levels (mg/dl) in nondiabetic rats on day 3 a day 7 at 0 and $1 \mathrm{hr}$.

\begin{tabular}{|llll|}
\hline Days & Time (Hr) & Group 1 & Group 2 \\
\hline \multirow{3}{*}{ Day 3 } & 0 & $65.50 \pm 6.89$ & $66.33 \pm 15.76$ \\
\cline { 2 - 4 } & 1 & $75.17 \pm 6.82$ & $90.83 \pm 15.61 * *$ \\
\cline { 2 - 4 } & $\mathrm{p}$ value & 0.064 & 0.0059 \\
\hline \multirow{3}{*}{ Day 7 } & 0 & $66.50 \pm 4.04$ & $70.67 \pm 5.79$ \\
\cline { 2 - 4 } & 1 & $70.33 \pm 8.09$ & $95.17 \pm 7.44 * *$ \\
\cline { 2 - 4 } & $\mathrm{p}$ value & 0.3499 & 0.0011 \\
\hline \multirow{2}{*}{$* * * \mathrm{p}<0.001, * * \mathrm{p}<0.01)$} & & \\
\hline
\end{tabular}

\section{Day 1: Non-diabetic groups (Between group comparisons)}

In euglycemic rats on day 1 , the absolute change in blood glucose level in group 2 was found to be significantly higher than the value in group 1 at 0.5 and $1 \mathrm{hr}$ (Table 4).

Table 4: Absolute change in mean blood glucose levels (mg/dl) in non-diabetic rats on day 1 at various time intervals in group1 and group 2.

\begin{tabular}{|lllll|}
\hline \multirow{2}{*}{ Groups } & Time in hr & & & $\mathbf{4}$ \\
\hline Group 1 & $\mathbf{0 . 5}$ & $\mathbf{1}$ & $\mathbf{2}$ & $7.83 \pm 7.68$ \\
\hline Group 2 & $6.00 \pm 4.77$ & $16.17 \pm 7.08$ & $9.00 \pm 10.14$ & $16.67 \pm 7.81$ \\
\hline p value: unpaired 't' & $30.33 \pm 15.56$ & $41.17 \pm 16.85$ & $17.67 \pm 10.14$ & 0.0765 \\
\hline
\end{tabular}

On intergroup comparison between group 2 with group 1 at 2 hour and 4 hour interval, no significant difference in the absolute change in mean blood glucose levels were seen $(\mathrm{p}>0.05)$.
On Day 3 and day 7, changes in blood glucose levels in Group 2 were found to be significantly higher than the values in Group 1 ( $\mathrm{p}<0.01)$ (Table 5). 


\section{Day 3 and 7: Non-diabetic groups (Between group comparison)}

Table 5: Absolute change in mean blood glucose levels (mg/dl) in non-diabetic rats on day 3 and 7 at $1 \mathrm{hr}$ in group1 and group 2.

\begin{tabular}{|lll|}
\hline \multirow{2}{*}{ Groups } & Day 3 & Day 7 \\
& Time & \\
\hline Group 1 & $\mathbf{~ h r}$ & $\mathbf{1 ~ h r}$ \\
\hline Group 2 & $9.67 \pm 9.99$ & $3.83 \pm 9.11$ \\
\hline $\begin{array}{l}\text { p value } \\
\text { unpair 't' test }\end{array}$ & $24.5 \pm 13.07$ & $24.5 \pm 8.87$ \\
\hline
\end{tabular}

In diabetic rats on within group comparison, mean blood glucose values were found to be significantly decreased in group 4 from 0.5 hour onwards and in groups 6 at 1 hour onwards as compared to baseline value at 0 hour in respective group. In group 3 and 5 , there were no significant change in blood glucose level $(p>0.05)$ (Table $6)$.

\section{Day 1: Diabetic groups (Within Groups comparison)}

Asterisk indicates within group comparison with baseline value at 0 hour in respective group.

On day 3 and 7, the mean blood glucose levels at 1 hour were significantly low as compared to 0 hour in Groups 4 and Group 6. While, the Mean blood glucose level in the Group 3 and Group 5 at 1 hour were not significantly different as compared to 0 hour (Table 7).

Table 6: Mean blood glucose levels $(\mathrm{mg} / \mathrm{dl})$ in diabetic rats on day 1 at various time intervals in group 3, group 4, group 5 and group 6.

\begin{tabular}{|lllll|}
\hline Time (hr) & $\begin{array}{l}\text { Group 3 } \\
\text { (Diab. control) }\end{array}$ & $\begin{array}{l}\text { Group 4 } \\
\text { (Glib) }\end{array}$ & $\begin{array}{l}\text { Group 5 } \\
\text { (Tam) }\end{array}$ & $\begin{array}{l}\text { Group 6 } \\
\text { (Tam+ Glib) }\end{array}$ \\
\hline 0 & $349.83 \pm 40.08$ & $380.17 \pm 60.57$ & $431.00 \pm 32.31$ & $394.17 \pm 40.02$ \\
\hline 0.5 & $349.83 \pm 30.31$ & $350.00 \pm 64.61 * * *$ & $427.50 \pm 25.88$ & $368.17 \pm 31.61$ \\
\hline 1 & $349.17 \pm 42.82$ & $305.33 \pm 61.58^{* * *}$ & $425.00 \pm 32.37$ & $320.00 \pm 45.14 * * *$ \\
\hline 2 & $347.67 \pm 36.81$ & $287.67 \pm 69.38^{* * *}$ & $425.17 \pm 23.26$ & $320.50 \pm 47.18 * * *$ \\
\hline 4 & $333.83 \pm 43.17$ & $273.50 \pm 61.07 * * *$ & $427.00 \pm 42.42$ & $296.17 \pm 58.11 * * *$ \\
\hline p value: RM ANOVA & 0.7546 & $<0.0001$ & 0.9629 & $<0.0001$ \\
\hline
\end{tabular}

Table 7: Mean blood glucose levels (mg/dl) in diabetic rats on day 3 and day 7 at 0 and 1 hr in group 3, group 4, group 5 and group 6 (Day 3).

\begin{tabular}{|lllll|}
\hline Time (hr) & Group 3 (Control) & Group 4 (Glib) & Group 5 (Tam) & Group 6 (Tam+Glib) \\
\hline Day 3 & & & & \\
\hline 0 & $342.50 \pm 30.16$ & $338.67 \pm 39.47$ & $403.33 \pm 14.02$ & $410.50 \pm 56.53$ \\
\hline 1 & $334.67 \pm 31.47$ & $175.00 \pm 37.02 * *$ & $394.50 \pm 15.00$ & $333.83 \pm 58.06 * * *$ \\
\hline p value & 0.2066 & 0.0011 & 0.1094 & 0.0001 \\
\hline Day 7 & & & $337.50 \pm 51.11$ & $360.50 \pm 35.59$ \\
\hline 0 & $308.33 \pm 20.54$ & $315.83 \pm 40.59$ & $336.50 \pm 34.84$ & $313.33 \pm 28.75^{* * *}$ \\
\hline 1 & $306.33 \pm 27.76$ & $230.17 \pm 42.66^{* * *}$ & 0.9059 & 0.0001 \\
\hline p value & 0.7579 & 0.0001 & & \\
\hline
\end{tabular}

$(* * * \mathrm{p}<0.001, * * \mathrm{p}<0.01)$

In diabetic rats on Day 1, intergroup comparison between group 3, group 4, group 5 and group 6 was made for each time intervals by absolute change in mean blood glucose level which shows that 0.5 hour values of change in mean blood glucose levels in group 4 and group 6 were significantly lower than the values in group $3(p<0.05$, $\mathrm{p}<0.05$ resp). The 1 hour, 2 hour and 4 hour values of change in mean blood glucose level in group 4 and group 6 were significantly lower as compared to group 3 (p $<0.0001, \mathrm{p}<0.0001, \mathrm{p}<0.0001$ resp.) (Table 8).

\section{Diabetic groups (Between groups comparison)}

On Day 3 and 7, intergroup comparison between group 3, group 4, group 5 and group 6 was made for the each time intervals by absolute change in mean blood glucose level. On day 3 and day 7 , the 1 hour values of change in mean blood glucose levels in group 4 and group 6 were significantly lower as compared to values in group 3 $(\mathrm{p}<0.001, \mathrm{p}<0.01$ resp.). Also, the 1 hour values of change in mean blood glucose level in group 5 and group 6 were 
found to be significantly lower as compared to value in group 4 ( $\mathrm{p}<0.001, \mathrm{p}<0.001$ resp.) The 1 hour values of change in mean blood glucose level in group 6 were found to be significantly lower than the value in group 5 . $(\mathrm{p}<0.01)$ (Table 9).

Table 8: Absolute change in mean blood glucose level (mg/dl) in diabetic rats on day 1 at various time intervals in group 3, group 4, group 5 and group 6 (Day 1).

\begin{tabular}{|c|c|c|c|c|}
\hline \multirow{2}{*}{ Groups } & \multicolumn{4}{|l|}{ Time in hr } \\
\hline & 0.5 & 1 & 2 & 4 \\
\hline Group 3 & $0.00 \pm 14.35$ & $-0.67 \pm 31.10$ & $-2.17 \pm 13.79$ & $-16.00 \pm 11.24$ \\
\hline Group 4 & $-30.17 \pm 16.56$ & $-74.83 \pm 12.53$ & $-92.5 \pm 24.77$ & $-106.67 \pm 28.15$ \\
\hline Group 5 & $-3.5 \pm 15.67$ & $-6.00 \pm 7.72$ & $-5.83 \pm 20.27$ & $-4.00 \pm 23.82$ \\
\hline Group 6 & $-26 \pm 12.28$ & $-74.17 \pm 12.48$ & $-73.67 \pm 24.10$ & $-98.00 \pm 41.40$ \\
\hline p value: one way ANOVA & 0.0031 & $<0.0001$ & $<0.0001$ & $<0.0001$ \\
\hline \multirow{4}{*}{ Post hoc test } & \multirow{4}{*}{$\begin{array}{l}3 \text { vs. } 4 * \\
3 \text { vs. } 6 * \\
4 \text { vs. } 5 *\end{array}$} & 3 vs. $4 * * *$ & 3 vs. $4 * * *$ & 3 vs. $4 * * *$ \\
\hline & & 3 vs. $6 * * *$ & 3 vs. $6 * * *$ & 3 vs. $6 * * *$ \\
\hline & & 4 vs. $5 * * *$ & 4 vs. $5 * * *$ & 4 vs. $5 * * *$ \\
\hline & & 5 vs. $6 * * *$ & 5 vs. $6 * * *$ & 5 vs. $6 * * *$ \\
\hline
\end{tabular}

$(* \mathrm{p}<0.05, * * \mathrm{p}<0.01, * * * \mathrm{p}<0.001)$

\section{Day 3 and 7: Diabetic group (Between group comparison)}

Table 9: Absolute change in mean blood glucose levels (mg/dl) in diabetic rats on day 3 and day 7 at $1 \mathrm{hr}$ in group 3, group 4, group 5 and group 6.

\begin{tabular}{|c|c|c|}
\hline \multirow{3}{*}{ Groups } & Day 3 & Day 7 \\
\hline & \multicolumn{2}{|l|}{ Time } \\
\hline & 1 hr & $1 \mathrm{hr}$ \\
\hline Group 3 & $-7.83 \pm 13.23$ & $-2.00 \pm 15.05$ \\
\hline Group 4 & $-163.67 \pm 58.99$ & $-85.67 \pm 18.10$ \\
\hline Group 5 & $-8.83 \pm 11.13$ & $-1.00 \pm 19.71$ \\
\hline Group 6 & $-76.67 \pm 15.92$ & $-47.17 \pm 9.45$ \\
\hline $\begin{array}{l}\mathrm{p} \text { value } \\
\text { one way ANOVA }\end{array}$ & $<0.0001$ & $<0.0001$ \\
\hline \multirow{5}{*}{ Post hoc test } & 3 vs. $4 * * *$ & 3 vs. $4 * * *$ \\
\hline & 3 vs. $6 * *$ & 3 vs. $6 * *$ \\
\hline & 4 vs. $5 * * *$ & 4 vs. $5 * * *$ \\
\hline & 4 vs. $6 * * *$ & 4 vs. $6 * * *$ \\
\hline & 5 vs. $6 * *$ & 5 vs. $6 * *$ \\
\hline
\end{tabular}

$(* \mathrm{p}<0.05, * * \mathrm{p}<0.01, * * * \mathrm{p}<0.001)$

\section{DISCUSSION}

Tamsulosin has been reported to cause hyperglycemia in 3 patients with diabetes. ${ }^{6}$ There are no reports of effect of tamsulosin in euglycemic and diabetic rats. The present study was conducted in 2 parts, to investigate the effect of tamsulosin in normal rats and the effects of glibenclamide, tamsulosin and their combination in alloxan induced diabetic rats.

In euglycemic rats, on day 1 statistically significant increase in blood glucose levels was seen at 1 hour in both normal saline and tamsulosin groups as compared to baseline values. But on day 3 and day 7, a significant increase in blood glucose levels was observed at 1 hour with tamsulosin but not with normal saline. Increase in blood glucose levels at 1 hour in normal saline group was unexpected. This could be because of sympathetic over activity caused by pain of the repeated needle pricks and handling of the rats while estimating blood glucose levels in well restrained rats. This finding suggests that tamsulosin by itself causes rise in blood glucose levels in non diabetic rats. In diabetic rats, on day 1 , glibenclamide cause significant decrease in blood glucose levels from 30 min onwards but tamsulosin did not cause any significant change in blood glucose levels at all time intervals. Combination of glibenclamide and tamsulosin also caused significant decrease in blood glucose levels from 1 hour onwards. This suggests that tamsulosin delayed the hypoglycemic effect of glibenclamide. On day 3, glibenclamide caused $48 \%$ reduction in blood glucose levels at 1 hour whereas its combination with tamsulosin caused $18 \%$ reduction in blood glucose levels. This suggests that tamsulosin reduced the hypoglycemic effect of glibenclamide. Similarly on day 7, glibenclamide caused 26\% reduction in blood glucose levels at 1 hour whereas its combination with tamsulosin caused $13 \%$ reduction in blood glucose levels. Hyperglycemic effects of tamsulosin in normal rats need to be evaluated further to find out the underlying mechanism of action. Tamsulosin is a $\alpha_{1 \mathrm{~A}}$ receptor antagonist and adrenergic receptors are known to modulate blood glucose levels. Several studies have demonstrated that $\alpha_{1}$ receptor mediated increase in glucose uptake in rat muscle cells and adipocyte. ${ }^{9}$ Previous studies showed the presence of $\alpha_{1}$ adrenoceptor in rat skeletal muscle through quantitative autoradiography, ribonuclease protection assays and radioligand binding studies. ${ }^{10,11,12}$ Stimulation of $\alpha_{1}$ 
receptor leads to phospholipase $\mathrm{C}$ activation initiating hydrolysis of phosphatidylinositol biphosphonate. This leads to activation of protein kinase $\mathrm{C}$ by release of intracellular calcium and diacyglycerol. ${ }^{13}$ Lipids in the phosphatidylinositol biphosphonate pathway can be substrates for phosphatidylinositol 3-kinase $\left(\mathrm{PI}_{3} \mathrm{~K}\right)$, which is important kinase for glucose uptake. ${ }^{14,15}$ It can be postulated that tamsulosin might inhibit $\alpha_{1}$ receptor mediated glucose uptake in rat muscle cells and adipose tissue. This may explain the hyperglycemic effect of tamsulosin in normal rats and reduction of hypoglycemic effect of glibenclamide in diabetic rats.

In this study, tamsulosin had no significant effect on blood glucose levels in diabetic rats whereas tamsulosin has increased blood glucose levels in diabetic patients. ${ }^{6}$ This difference could be because of interspecies difference. Prazosin and Doxazosin have shown beneficial effect on glucose metabolism in human by lowering insulin resistance. ${ }^{8}$ Doxazosin has shown beneficial effect on glucose control in diabetes mellitus. ${ }^{7}$ Thus $\alpha$ receptor antagonist may have variable effect on blood glucose levels in diabetic patients.

Borgsteede et al, observed 3 cases of hyperglycemia in association with the use of Tamsulosin for the treatment of BPH. All patients used insulin for diabetes. On above case reports, author concluded that non insulin dependent pathway may also contribute to glucose uptake, one of these regulated by the $\alpha_{1}$ receptor. $^{6}$

The role of the $\alpha_{1}$ receptor in glucose uptake in humans was also shown. In two studies, one in healthy and the other in obese subjects, interstitial glucose concentrations were measured using micro dialysis. ${ }^{16,17}$ Stimulation with a $\alpha_{1}$-agonist resulted in a decrease of interstitial glucose concentrations. ${ }^{16,17}$ The $\alpha_{1}$ antagonist uradipil was able to inhibit $\alpha_{1}$-agonist induced glucose decrease. ${ }^{17}$ Also, $\alpha_{1}$ receptor stimulation increased glucose intake in human adipose tissue. ${ }^{16,17}$ Inhibition of the $\alpha_{1}$ receptor pathway can result in a decreased glucose uptake, and hence an increased glucose plasma concentration.

Manjunath et al. in their study carried on alloxan induced diabetic rats have concluded that clonidine has hyperglycemic effects and also interact with glibenclamide to reduce its hypoglycemic activity. ${ }^{1}$ Clonidine is $\alpha_{2}$ receptor agonist and these authors have proposed that this hyperglycemia could be due to inhibition of insulin release, stimulation of growth hormone release and due to increased hepatic glycogenolysis by clonidine. In this study, we also found that tamsulosin interact with glibenclamide to reduce its hypoglycemic activity, however tamsulosin did not cause hyperglycemia in diabetic rats. Thus, in any situation where tamsulosin is used in diabetic patient who is on sulfonylureas, there is possibility of interaction leading to decrease effect of sulfonylurea.
To our knowledge there are no reported studies on effect of tamsulosin on blood glucose levels in euglycemic and diabetic rats and therefore our results suggest that tamsulosin could alter blood glucose levels in euglycemic rats and reduce the hypoglycemic effect of glibenclamide in diabetic rats. In this study, 12 normal rats who were given normal saline and tamsulosin were reused for induction of diabetes after washout period of 10 days. This was done keeping in mind reduction in number of animals to be used for research on animals.

This study has many limitations; the exact mechanism of action of tamsulosin on blood glucose levels was not evaluated. The investigation like measurement of insulin levels and C-peptide levels were not done, due to lack of required facility and financial support. Measurement of these parameters can give some clue to observed effect on blood glucose levels.

Authors used alloxan induced diabetic rats for our study. However, streptozotocin induced diabetes offer many advantages over alloxan such as less mortality, more percent chance of diabetes induction and less chance of reversibility of diabetes. Although, alloxan induced diabetes is model for type 1 diabetes, in this study, glibenclamide significantly decreased blood glucose levels in diabetic rats and similar result are seen in previous studies. ${ }^{1,18}$ The primary action of sulfonylureas is to stimulate release of insulin by the pancreatic beta cells; they also have extra pancreatic action, they may also reduce hepatic clearance of insulin, and serum glucagon levels. ${ }^{19,20}$

The hyperglycemic effect of tamsulosin should be further evaluated in other animals models of diabetes like streptozotocin induced diabetes rats and rabbits and models of type 2 diabetes such as monogenic and polygenic rats. Future studies should also evaluate interaction of tamsulosin with insulin and other oral antidiabetic drugs. Estimation of insulin levels and Cpeptide levels should be done in an attempt to find out possible mechanism of drug interaction. There is a need for close monitoring of blood glucose levels in patients suffering from DM and BPH who are likely to be prescribed tamsulosin or other $\alpha_{1}$ receptor antagonist.

\section{CONCLUSION}

To conclude our study shows that tamsulosin significantly increased blood glucose levels in euglycemic rats and it interact with glibenclamide to reduce its hypoglycemic activity in alloxan induced diabetic rats. If this finding are true to human being tamsulosin should be used with caution with in diabetic patients on glibenclamide therapy as it may reduce the hypoglycemic activity of glibenclamide. Further studies are required to understand these interactions and its clinical implication. 


\section{ACKNOWLEDGEMENTS}

Authors would like to thank HOD, Guide, all colleagues, their parents and the patients for their collaboration.

\section{Funding: No funding sources}

Conflict of interest: None declared

Ethical approval: The study was approved by the Institutional Ethics Committee

\section{REFERENCES}

1. Manjunath S, Santosh N. Kugali, Priyadarshani M. Deodurg. Effect of clonidine on glucose level in euglycemic and alloxan-induced diabetic rats and its interaction with glibenclamide. Ind $\mathrm{J}$ Pharmacol ,2010;41(5):218-20.

2. Parsons JK, Carter HB, Partin AW, Windham BG, Metter EJ, Ferrucci L, et al. Metabolic factors associated with benign prostatic hyperplasia. J Clin Endocrinol Metab. 2006;91(7):2562-8.

3. Brady PA, Terzic A, The sulfonylurea controversy: more question from the heart. J Am Coll Cardiol. 1998;31(5):950-6.

4. Zanten U, Schwanstecher M, Schwanstecher C. Sulfonylurea receptors and mechanism of sulfonylurea action. Exp Clin Endocrinol Diabetes. 1996;104(1):19.

5. Denis L, McConnell J, Yoshida O. Recommendations of the International Scientific Committee: the evaluation and treatment of lower urinary tract symptoms (LUTS) suggestive of benign prostatic obstruction. In: Denis L, Griffiths K, Khoury S, et al, eds. Proceedings of the $4^{\text {th }}$ International Consultation on Benign Prostatic Hyperplasia, Plymouth, UK: Health Publication Ltd; 1998:669-683.

6. Borgsteede S, Bruggeman $\mathrm{R}$, Hoefnagel R. Tamsulosin and hyperglycaemia in patients with diabetes. J Med of Netherl. 2010;68(3):141-3.

7. Derosa G, Cicero AF, Gaddi A, Mugellini A, Ciccarelli L, Fogari R. Effects of doxazosin and irbesartan on blood pressure and metabolic control in patients with type 2 diabetes and hypertension. J Cardiovasc Pharmacol. 2005;45(6):599-604.

8. Inukai $\mathrm{T}$, Inukai $\mathrm{Y}$, Matsutomo $\mathrm{R}$, Okumura $\mathrm{K}$, Takanashi K, Takebayashi K, et al. Clinical usefulness of doxazosin in patients with type 2 diabetes complicated by hypertension: effects on glucose and lipid metabolism. J Int Med Res. 2004;32(2):206-13.
9. Faintrenie G, Geloen A. $\alpha 1$ adrenergic stimulation of glucose uptake in rat white adipocytes. J Pharmacol Exp Ther. 1998;286(2):607-10.

10. Martin III WH, Tolley TK, Saffitz JE. Autoradiographic delineation of skeletal muscle $\alpha 1$ adrenergic receptor distribution. Am J Physiol. 1990;259:H1402-H1408.

11. Rokosh DG, Bailey BA, Stewart AF. Distribution of $\alpha 1 \mathrm{C}$-adrenergic receptor mRNA in adult rat tissues by RNase protection assay and comparison with $\alpha 1 \mathrm{~B}$ and a1D. Biochem Biophys Res Commun. 1994;200:1177-84.

12. Rattigan S, Appleby GJ, Edwards SJ, McKinstry WJ. $\alpha$-adrenergic receptors in rat skeletal muscle. Biochem Biophys Res Commun. 1986;136:1071-7.

13. Zhong H, Minneman KP. $\alpha 1$-Adrenoceptor subtypes. Eur J Pharmacol. 1999;375:261-76.

14. Cheng JT, Liu IM, Yen ST, Chen PC. Role of $\alpha 1 \mathrm{~A}-$ adrenoceptor in the regulation of glucose uptake into white adipocyte of rats in vitro. Auton Neurosci. 2000;84(3):140-6.

15. Doenst T, Taegtmeyer H. $\alpha$-Adrenergic stimulation mediates glucose uptake through phosphatidylinositol 3-kinase in rat heart. Circ Res. 1999;84:467-74.

16. Boschmann M, Krupp G. In vivo response to $\alpha 1$ adrenoreceptor stimulation in human white adipose tissue. Obes Res. 2002;10(6):555-8.

17. Flechtner-Mors M, Jenkinson CP, Alt A, Biesalski HK, Adler G, Ditschuneit HH. Sympathetic regulation of glucose uptake by the $\alpha 1$-adrenoceptor in human obesity. Obes Res. 2004;2(4):612-20.

18. Aileen JFK. Review: The use of animal models in diabetes research. Brit Jour of Phar. 2012;166:877-94.

19. Onyije FM, Avwioro OG. Effect of Ethanolic Extract of Bauhinia Monandra Leaf on the Liver of Alloxan Induced Diabetic Rats. J Phys Pharm Adv. 2012;2(1):59-63.

20. Martha S. Pancreatic Hormones and Antidiabetic Drugs. In: Katzung BG, Masters SB, Trevor AJ (eds.) Basic and clinical pharmacology. $11^{\text {th }}$ Edi. New Delhi: Tata McGraw Hill education private limited; 2010:727-752.

Cite this article as: Satpute S, Nerurkar R, Kokne M. Effect of tamsulosin on blood glucose levels in euglycemic and alloxan induced diabetic rats and its interaction with glibenclamide. Int J Basic Clin Pharmacol 2018;7:1599-605. 